\title{
PEMBAYARAN KLAIM ASURANSI JIWA AKIBAT TERTANGGUNG BUNUH DIRI (PT ASURANSI JIWA MANULIFE INDONESIA)
}

\author{
Oleh
}

\author{
Hilda Yunita Sabrie*
}

\begin{abstract}
Abstrak
Pertumbuhan bisnis asuransi di Indonesia mengalami peningkatan yang luar biasa. Namun untuk beberapa golongan masyarakat masih ada yang belum mengerti tentang pentingnya berasuransi. Hal ini dapat disebabkan antara lain karena citra yang kurang baik dari perusahaan asuransi atau penanggung dalam memberikan klaim asuransi kepada tertanggung atau penerima manfaat. Untuk itu diperlukan itikad baik antar pihak dalam melakukan perjanjian asuransi.
\end{abstract}

Kata Kunci : asuransi, perusahaan asuransi, itikad baik, tertanggung

\section{PENDAHULUAN}

Hingga saat ini perkembangan ekonomi dan industri yang semakin progresif menimbulkan implikasi yang juga semakin kompleks bagi pertumbuhan bisnis asuransi di Indonesia. Tetapi perlu diakui bahwa sangat sulit meyakinkan masyarakat terhadap pentingnya asuransi bagi diri pribadi, keluarga maupun harta benda. Bahkan bila melihat jumlah pemegang polis asuransi, boleh dikatakan masyarakat memiliki kesadaran yang sangat kurang terhadap asuransi (uninsurance minded). ${ }^{1}$

Menurut Hotbonar Sinaga, mantan ketua Dewan Asuransi Indonesia (DAI),

*PT Bank Jatim Cabang Utama, hilda_sabrie@ yahoo.co.id

${ }^{1}$ www.pesankonsumen.com ada tiga penyebab rendahnya kesadaran masyarakat Indonesia untuk berasuransi, yaitu rendahnya kemampuan ekonomis masyarakat yang berdampak pada rendahnya daya beli, minimnya dan kurang opimalnya promosi dan sosialisasi yang dilakukan oleh industri asuransi kepada masyarakat Indonesia serta buruknya citra asuransi di mata masyarakat. $^{2}$

Asuransi atau pertanggungan, menurut Pasal 246 Kitab Undang-Undang Hukum Dagang (KUHD) didefinisikan sebagai berikut:

Asuransi atau pertanggungan adalah suatu perjanjian, dengan mana seorang penanggung mengikatkan diri kepada

\footnotetext{
${ }^{2}$ www.republika.com
} 
seorang tertanggung dengan menerima suatu premi, untuk memberikan penggantian kepadanya karena suatu kerugian, kerusakan atau kehilangan keuntungan yang diharapkan, yang mungkin akan dideritanya karena suatu peristiwa yang tak tertentu.

Asuransi dalam Pasal 1 (1) UndangUndang Nomor 2 tahun 1992 tentang Usaha Perasuransian (UU Usaha Perasuransian), didefinisikan sebagai berikut:

Asuransi atau pertanggungan adalah perjanjian antara dua pihak atau dengan mana pihak penanggung mengikatkan diri kepada pihak tertanggung, dengan menerima premi asuransi, untuk memberikan penggantian kepada tertanggung karena kerugian, kerusakan, atau kehilangan keuntungan yang diharapkan atau pertangungan yang timbul dari suatu peristiwa yang tidak pasti atau untuk pembayaran yang di dasarkan atau hidupnya seseorang yang dipertanggungkan.

Mengacu pada definisi tersebut di atas dapat ditarik kesimpulan bahwa asuransi adalah suatu perjanjian dimana pihak penanggung mengikatkan dirinya kepada pihak tertanggung untuk menerima pembayaran sejumlah premi, yang nantinya pihak penanggung akan memberikan suatu penggantian atas kerugian, kerusakan, kehilangan keuntungan yang diharapkan oleh tertanggung yang timbul dari peristiwa tidak pasti. Perbedaan yang tampak dalam definisi asuransi menurut KUHD dengan UU
Usaha Perasuransian adalah adanya jenis pertanggungan asuransi jiwa dalam Pasal 1 (1) UU Usaha Perasuransian, sedangkan di dalam KUHD definisi asuransi tidak mencakup asuransi jiwa, namun asuransi jiwa diatur secara khusus dalam Pasal 302308 KUHD. ${ }^{3}$ Sehingga bila ditelaah lebih lanjut substansi dari pasal tersebut pada pokoknya ada dua jenis asuransi yaitu:

a. Asuransi kerugian (Schade Verzekering), yang meliputi asuransi kebakaran, asuransi pertanian, asuransi laut, serta asuransi pengangkutan;

b. Asuransi Jumlah (Sommen Verzekering), meliputi asuransi jiwa dan asuransi kesehatan.

Ada beberapa hal mendasar yang membedakan antara asuransi jumlah dengan asuransi kerugian. Perbedaan pertama terletak pada konsep penerapan suatu peristiwa tidak pasti. Dalam asuransi jumlah, suatu peristiwa dikatakan sebagai peristiwa tidak pasti apabila terjadi gangguan terhadap kesehatan tertanggung atau kematian tertanggung selama tenggang waktu yang disebutkan dalam polis, hal ini berbeda dalam asuransi kerugian. Dalam asuransi kerugian, suatu peristiwa dikatakan sebagai peristiwa tidak pasti apabila pada masa tenggang waktu yang tersebut dalam polis terjadi hal-hal yang mengakibatkan kerugian pada obyek yang diasuransikan, misalnya obyek asuransi tersebut hilang, rusak atau terbakar.

Perbedaan kedua terletak pada penetapan besarnya uang pertanggungan.

\footnotetext{
${ }^{3}$ Bimbingan Skripsi, tanggal 14 September 2007.
} 
Dalam asuransi jumlah, besar uang pertanggungan telah ditetapkan terlebih dahulu, sedangkan pada asuransi kerugian besarnya uang pertanggungan dihitung dengan cara membandingkan harga barang yang rusak sebagai akibat hilang/ terbakar dengan harga barang sebelum timbul kehilangan / kebakaran.

Pengaturan tentang asuransi jiwa di dalam KUHD terdapat pada Pada Pasal 302 yang menyatakan sebagai berikut : "Jiwa seseorang dapat, guna keperluan seorang yang berkepentingan, dipertanggungkan baik untuk selama hidupnya jiwa itu, baik untuk suatu waktu yang ditetapkan dalam perjanjian." Sehingga secara luas asuransi jiwa dapat diartikan sebagai suatu perjanjian di mana satu pihak mengikatkan dirinya untuk membayar sejumlah uang, secara sekaligus atau periodik, sedang pihak lain mengikatkan dirinyauntuk membayar premi, dan pembayaran uang itu adalah tergantung kepada mati atau hidupnya seorang tertentu atau lebih. ${ }^{4}$

Apabila asuransi jiwa berakhir setelah tenggang waktu yang ditentukan, sedang orang yang bersangkutan masih hidup, maka asuransi itu pada akhirnya sama atau serupa dengan suatu penabungan uang belaka. Hanya saja uang yang di tabung dan yang dibayarkan pada akhir tenggang waktu tersebut biasanya jumlahnya kurang dari jumlah premi yang telah dibayarkan. ${ }^{5}$

${ }^{4}$ Djoko Prakoso, Hukum Asuransi Indonesia, Rineka Cipta, Jakarta, 2004, h. 281 dikutip dari Ny Dani Pangaribuan Simanjuntak, Hukum Pertanggungan (Pertanggungan kerugian pada umumnya, keakaran dan jiwa),Seksi Hukum Dagang Fakultas Universitas Gajah Mada, Yogyakarta, 1975, h.114.

${ }^{5}$ Djoko Prakoso S.H, ibid, h. 283.
Bila dalam hal tersebut di atas, ternyata tertanggung meninggal dunia, maka uang yang dibayarkan oleh perusahaan asuransi (penanggung) akan diterima oleh penerima manfaat yang ditunjuk.

Tetapi dalam KUHD juga mengatur mengenai pembatasan tanggungjawab oleh penanggung kepada tertanggung atau penerima manfaat, dalam hal membayar uang pertanggungan. Salah satu pembatasan tangungjawab penanggung adalah ketika pihak tertanggung meninggal dunia karena bunuh diriatau dihukum mati sepertiyang ada pada Pasal 307 KUHD, pihak penanggung tidak diwajibkan untuk membayar uang pertanggungan apabila tertanggung dalam masa pertanggungan meninggal dunia karena bunuh diri atau dihukum mati, maka dalam hal ini pertanggungan dianggap gugur. Sehingga menurut KUHD, pihak penerima manfaat dapat saja tidak akan menerima pembayaran uang pertanggungan dari perusahaan asuransi jiwa.

Pengertian bunuh diri atau suicide menurut Black's Law Dictionary adalah : "The act or an instance of taking one's own life voluntarily and intentionally : self destruction." 6 Sehingga dapat diartikan bahwa bunuh diri merupakan tindakan atau desakan untuk mengambil kehidupan diri sendiri secara sukarela dengan maksud untuk membinasakan diri sendiri.

Dalam Kitab Undang-Undang Hukum Pidana(KUHP) mengaturtentangduamacam bunuh diri yaitu bunuh diri yang dilakukan atas bantuan seseorang atau beberapa orang

${ }^{6}$ Henry Campbel, Black's Law Dictionary, ST Paul, MINN, West Publishing Co,1990, h.2286. 
dan bunuh diri yang dilakukan atas anjuran atau dorongan dari pihak lain. Konsep ini berbeda dalam hukum asuransi jiwa karena yang dimaksud bunuh diri menurut Pasal 307 KUHD adalah tindakan yang dilakukan oleh diri sendiri secara sukarela dan atas motif tertentu. Artinya tidak ada pihak lain yang membantu maupun menganjurkan untuk bunuh diri. Biasanya pelaku bunuh diri dilanda keputusasaan dan depresi karena cobaan hidup, kurang sehatnya akal atau tekanan lingkungan. ${ }^{7}$ Pada Pasal 307 KUHD ini juga memberi pengertian bahwa tertanggung sendirilah yang mempertanggungkan jiwanya dan dia sendirilah yang bunuh diri atau dihukum mati. Dengan demikian penanggung dapat dibebaskan untuk tidak membayar uang pertanggungan apabila tertanggung meninggal dunia karena bunuh diri atau akibat dihukum mati.

Pada prakteknya sering kali terjadi tertanggung lalai dalam membaca, mempelajari dan memahami isi polis sehingga akan berakibat pada pengajuan klaim ditolak oleh penanggung. Dalam polis biasanya terdapat janji-janji khusus yang membatasi tanggung jawab penanggung, seperti yang ada pada ketentuan umum polis PT Asuransi Jiwa Manulife Indonesia yang terkait dengan meninggalnya tertanggung akibat bunuh diri. Pada PT Asuransi Jiwa Manulife Indonesia, penanggung akan tetap membayar uang pertanggungan apabila tertanggung meninggal karena bunuh diri tetapi dengan syarat-syarat tertentu. Hal ini berbeda dengan Pasal 307 KUHD, yang

${ }^{7} \underline{w w w}$. idwikipedia. com membebaskan pihak penanggung untuk memberikan uang pertanggungan kepada penerima manfaat.

Melihat dari penjelasan yang telah terurai di atas, perihal pembayaran klaim dalam asuransi jiwa, rumusan masalah yang dapat diketengahkan adalah apakah pembayaran klaim kepada penerima manfaat akibat tertanggung meninggal dunia karena bunuh diri sesuai dengan prinsip-prinsip perjanjian asuransi jiwa yang ada dan bagaimana prosedur pembayaran klaim asuransi jiwa akibat tertanggung bunuh diri menurut PT Asuransi Jiwa Manulife Indonesia

\section{Prinsip-Prinsip Perjanjian Asuransi Jiwa}

Suatu perjanjian adalah suatu peristiwa dimana seorang berjanji kepada seorang lain atau dimana dua orang itu saling berjanji untuk melaksanakan sesuatu hal. Dari peristiwa itu, timbullah suatu hubungan antara dua orang tersebut yang dinamakan perikatan. Kedua belah pihak dapat berupa naturlijk persoon atau manusia pribadi dan recht persoon atau badan hukum. Dalam bentuknya, perjanjian itu berupa suatu rangkaian perkataan yang mengandung janji-janji atau kesanggupan yang diucapkan atau ditulis. ${ }^{8}$

Seperti halnya perjanjian pada umumnya, dalam perjanjian asuransi jiwa harus memperhatikan syarat sahnya perjanjian yakni adanya kata sepakat, cakap dalam membuat perjanjian, mengenai suatu

${ }^{8}$ Subekti, Hukum Perjanjian, Intermasa, cetakan keduapuluhsatu, Jakarta, 2005, h.1. 
hal tertentu dan yang terakhir adalah suatu sebab atau causa yang diperbolehkan. Apabila syarat sahnya perjanjian ini telah dipenuhi maka menurut Pasal 1338 (1) BW, para pihak diberi kewenangan untuk dapat menentukan sendiri isi dari perjanjian tersebut. Isi perjanjian yang dibuat oleh para pihak tidak boleh bertentangan dengan kesusilaan, ketertiban umum dan undangundang.

Selain harus memenuhi syarat sahnya perjanjian yang ada di Pasal 1320 jo 1338 BW, dalam perjanjian asuransi jiwa juga harus memperhatikan prinsip-prinsip yang ada di dalam KUHD. Prinsip yang pertama adalah prinsip insurable interest, prinsip ini merupakan manifestasi dari syarat sah perjanjian yang ada pada Pasal 1320 (3) BW yaitu suatu hal tertentu. ${ }^{9}$ Dalam KUHD, prinsip ini diatur di dalam Pasal 250 KUHD, yang menjelaskan mengenai "pihak yang berkepentingan" sebagai berikut :

Apabilaseorang yang telah mengadakan pertanggungan untuk dirinya sendiri, atau apabila seorang, yang untuknya telah diadakan suatu pertanggungan, pada saat diadakannya pertanggungan itu tidak mempunyai kepentingan terhadap barang yang dipertanggungkan itu, maka penanggung tidaklah diwajibkan memberikan ganti rugi.

Maka jika disimpulkan, ketentuan diatas mensyaratkan adanya kepentingan dalam mengadakan perjanjian asuransi dengan akibat batalnya perjanjian tersebut

\footnotetext{
${ }^{9}$ Bimbingan Skripsi, tanggal 28 Desember 2007.
}

apabila pasal ini tidak dipenuhi. Pasal 268 KUHD memberikan penjelasan mengenai syarat-syarat kepentingan yang dapat diasuransikan yaitu dapat dinilai dengan uang, dapat diancam oleh suatu bahaya, dan tidak dikecualikan oleh undang-undang. Pasal ini mempunyai pengertian yang sempit, mengingat kepentingan harus dapat dinilai dengan uang sedangkan masih ada kepentingan yang tidak dapat dinilai dengan uang misalnya hubungan kekeluargaan, jiwa, istri, anak dan lain-lain. ${ }^{10}$

Secara moril, kepentingan di dalam perjanjian asuransi jiwa tidak pantas untuk dinilai dengan uang. Tetapi bukan berarti hal tersebut tidak dapat ditentukan dengan uang. Dalam Asuransi jiwa, kepentingan yang dapat diasuransikan adalah sesuatu dugaan akan hilangnya atau berkurangnya nilai ekonomis yang timbul karena meninggalnya orang yang jiwanya diasuransikan (tertanggung). Artinya jika tertanggung meninggal dunia maka dari segi ekonomi, hal tersebut dapat mengganggu perjalanan hidup penerima manfaat. Sehingga besarnya uang pertanggungan yang nantinya akan diberikan oleh penanggung, dapat dinilai sebagai bentuk dari penggantian nafkah yang biasanya diterima oleh penerima manfaat saat tertanggung masih hidup. Hal inilah yang dapat dikatakan sebagai kepentingan yang dapat dinilai dengan uang dalam perjanjian asuransi jiwa.

Syarat kepentingan ini harus ada pada

${ }^{10}$ Chairul Huda dan Lukman Hakim, Tindak Pidana Dalam Bisnis Asuransi, Lembaga Pemberdayaan Hukum Indonesia (LPHI), cetakan pertama, Jakarta, 2006, h.4. dikutip dari M.Suparman dan Endang, Hukum Asuransi (Perlindungan Tertanggung, Asuransi Deposito, Usaha Perasuransian), Alumni, Bandung, 2003, h.55-56. 
saat perjanjian asuransi jiwa diadakan, pelanggaran pasal ini dapat menyebabkan penanggung tidak diwajibkan untuk memberikan ganti rugi. Sedangkan menurut pendapat beberapa ahli hukum, kepentingan tidak harus ada pada saat perjanjian asuransi dibuat, melainkan harus ada pada saat peristiwa yang menimbulkan kerugian itu terjadi. Pada saat itulah muncul kepentingan yang nantinya dapat dipakai untuk menentukan ada atau tidaknya ganti kerugian. Hal ini dapat dipahami karena perjanjian asuransi jiwa baru mempunyai arti bagi tertanggung justru pada saat terjadi peristiwa tidak pasti. ${ }^{11}$

Menurut KUHD, perjanjian asuransi jiwa hanya boleh berlaku bila pemegang polis mempunyai insurable interest atas hidup orang yang jiwanya diasuransikan. Sebagai contoh adalah seseorang memiliki insurable interest atas dirinya, maka ia dapat menutup perjanjian asuransi jiwa atas dirinya. Contoh lainnya adalah Seorang anak mempunyai insurable interest atas ayah dan ibunya karena ia mempunyai kepentingan atas ayah dan ibunya, maka ia dapat menutup perjanjian asuransi jiwa atas ayah dan ibunya. ${ }^{12}$

Prinsip yang kedua adalah prinsip Indemnity dimana menurut prinsip ini perjanjian asuransi itubertujuan memberikan ganti rugi terhadap kerugian yang diderita oleh tertanggung yang disebabkan oleh

11 Abulkadir Muhammad, Pokok-Pokok Hukum Pertanggungan, Citra Aditya Bakti, cetakan ketiga, Jakarta, 1977, (selanjutnya disingkat Abdulkadir Muhammad I), h.42

${ }^{12}$ Radiks Purba, Memahami Asuransi di Indonesia, Pustaka Binaman Pressindo, seri umum ke 10, Jakarta, 1992, h. 116 bahaya sebagaimana yang telah ditentukan didalam polis. Pihak penanggung bersedia membayar ganti rugi sebesar nilai kerugian riil yang diderita oleh tertanggung, tidak lebih. Hal ini dapat dikaitkan dengan fungsi asuransi yaitu mengalihkan atau mengurangi risiko yang kemungkinan diderita atau dihadapi oleh tertanggung karena terjadi suatu peristiwa yang tidak pasti. Oleh karena itu besarnya ganti rugi yang diterima oleh tertanggung harus seimbang dengan kerugian yang diderita.

Prinsip indemnitas ini diatur salah satunya dalam Pasal 252 KUHD yaitu "kecuali dalam hal-hal yang disebutkan dalam ketentuan undang-ungang, maka tidak bolehlah diadakan suatu petanggungan kedua,untuk jangka waktu yang sudah dipertanggungkankan untuk harganya penuh,dan demikian itu atas ancaman batalnya petanggungan kedua tersebut." Pasal ini menjelaskan bahwa tertanggung tidak diperbolehkan untuk mendapatkan keuntungan dari penanggung atas kerugian yang ia derita kecuali ditentukan lain oleh undang-undang.

Sehingga untuk mewujudkan keseimbangan antara kerugian dengan ganti rugi yang diberikan oleh penanggung, maka harus diketahui berapa nilai atau harta dari objek yang diasuransikan. ${ }^{13}$ Untuk itu dapat dikatakan bahwa prinsip ganti rugi atau indemnity ini, tidak dapat diterapkan dalam asuransi jiwa karena pembayaran sejumlah uang dari penanggung kepada tertanggung atau penerima manfaat

${ }^{13}$ M.Suparman Sastrawidjaja, Aspek-Aspek Hukum Asuransi dan Surat Berharga,Alumni, Bandung, 1997,h.70-71 
bukanlah merupakan suatu bentuk ganti rugi melainkan pembayaran sejumlah uang yang telah disepakati oleh para pihak pada awal perjanjian asuransi jiwa.

Selain prinsip-prinsip yang telah diuraikan diatas, prinsip ketiga adalah prinsip subrogasi yang diatur dalam Pasal 284 KUHD yakni :

Seorang penanggung yang telah membayar kerugian sesuatu barang yang diasuransikan, menggantikan pihak tertanggung dalam segala hak yang diperolehnya terhadap orangorang ketiga berhubung dengan penerbitan kerugian tersebut; dan pihak tertanggung itu yang bertanggung jawab untuk setiap perbuatan yang dapat merugikan hak si penanggung terhadap orang-orang ketiga itu.

Subrogasi dalam asuransi, secara umum dapat dijelaskan bahwa kerugian yang diderita oleh tertanggung akan diganti oleh penanggung tetapi jika kerugian tersebut diakibatkan oleh bahaya (risiko) yang ditanggung oleh polis. Jika tertanggung telah memperoleh ganti rugi dari penanggung, maka secara yuridis, tertanggung tidak berhak lagi untuk menuntut ganti rugi dari pihak lain, yaitu dari pihak yang bertanggung jawab atas penyebab dari kerugian tersebut. ${ }^{14}$

Dalamhaliniyangberhakmenuntutganti rugi kepada pihak lain adalah penanggung. Atas tuntutan tersebut, pihak tertanggung wajib membuat "surat subrogasi" untuk diserahkan kepada pihak penanggung, yang

${ }^{14}$ Djoko Prakoso, opcit, h. 189 berarti hak dari tertanggung untuk menuntut pihak yang bertanggung jawab atas kerugian tersebut berpindah kepada penanggung. Peralihan hak dari tertanggung kepada penanggung berlangsung secara otomatis sejak penanggung membayar ganti rugi kepada tertanggung, tetapi dalam rangka pelaksanaan tuntutan ganti rugi kepada pihak yang bertanggung jawab atas kerugian tersebut penanggung tetap memerlukan surat subrogasi ${ }^{15}$.

Istilah subrogasi juga dapat ditemui dalam Pasal 1400 BW. Pada pasal tersebut subrogasi atau penggantian hak-hak ini ada apabila dalam suatu perjanjian hutangnya dibayar oleh pihak ketiga dengan akibat bahwa pihak ketiga itu menggantikan pihak yang berhak dalam hak-hak yang berakar pada perjanjian itu sehingga hak-hak itu berpindah dari pihak yang berhak kepada pihak ketiga yang membayar hutangnya tadi. Dalam hal ini "pihak ketiga" adalah orang yang menggantikan pihak yang berhak dalam suatu perjanjian, sedangkan dalam asuransi yang disebut "pihak ketiga" adalah pihak yang berkewajiban membayar kepada orang yang menggantikan pihak yang berhak.

Prinsip subrogasi ini tidak dapat diterapkan di dalam perjanjian asuransi jiwa. Sama halnya dengan prinsip indemnitas yaitu dalam perjanjian asuransi jiwa, pembayaran sejumlah uang dari penanggung kepada tertanggung atau penerima manfaat bukanlah merupakan suatu bentuk ganti rugi. Sehingga subrogasi yang dilaksanakan

\footnotetext{
15 Chairul Huda dan Lukman Hakim,opcit, h.13
} 
oleh penanggung kepada pihak ketiga di dalam perjanjian asuransi jiwa adalah tidak tepat sebab pihak ketiga tidak menimbulkan suatu kerugian, lagi pula pembayaran uang pertangungan dari penanggung adalah jumlah uang pertangungan yang telah disepakati sebelumnya.

Prinsip yang terakhir adalah prinsip itikad baik. Setiap perjanjian termasuk perjanjian asuransi jiwa, harus dilaksanakan dengan itikad baik (Principle of Utmost Good Faith). Pada perjanjian asuransi jiwa unsur paling utama adalah unsur saling percaya dimana pihak penanggung percaya bahwa tertanggung akan memberikan keterangan yang sebenar-benarnya dalam surat permohonan asuransi jiwa sampai dengan permohonan klaim asuransi jiwa bila terjadi peristiwa tidak pasti.

Sedangkan untuk tertanggung sendiri akan percaya kepada pihak penanggung bahwa jika terjadi peristiwa tidak pasti, nantinya pihak penanggung akan membayar uang pertanggungan. Saling percaya ini dasarnya adalah itikad baik yang ada pada kedua belah pihak (penanggung dan tertanggung). Prinsip itikad baik ini juga merupakan manifestasi dari syarat sahnya perjanjian yang diatur di dalam Pasal 1320 (1) BW yaitu adanya kata sepakat. ${ }^{16}$

Untuk asuransi jiwa, prinsip itikad baik ini dapat lebih jelas dilihat pada Pasal 251 KUHD yang terkait dengan kewajiban untuk memberikan keterangan yang sebenarnya. Dalam pasal tersebut perjanjian asuransi

\footnotetext{
${ }^{16}$ Bimbingan Skripsi, tanggal 28 Desember 2007.
}

jiwa akan menjadi batal apabila tertanggung memberikan keterangan yang keliru atau tidak benar, tanpa melihat apakah pihak tertanggung beritikad baik atau buruk. Jadi apabila seorang tertanggung diketahui telah memberikan keterangan yang keliru atau fakta yang tidak benar terkait dengan keadaan tertanggung, maka penanggung sebagai pihak yang merasa dirugikan dapat menolak klaim yang diajukan oleh tertanggung atau penerima manfaat.

Sehingga hal-hal yang dianggap sebagai pelanggaran terhadap prinsip Utmost Good Faith pada dasarnya terdiri atas 4 (empat) macam yang dapat menyebabkan batalnya suatu perjanjian asuransi jiwa yaitu ${ }^{17}$ :

\section{a. Innocent Misrepresentation} yaitu kekurangtelitian dari calon tertanggung dalam menyampaikan fakta-fakta materiil (penting), yang disebabkan oleh kurangnya pengetahuan tertanggung atas faktafakta tersebut, sehingga tidak ada faktor kesengajaan;

b. Fraudulent Misrepresentation yaitu suatu perbuatan yang dengan sengaja menutupi atau mengurangi penjelasan mengenai fakta-fakta materiil yang seharusnya disampaikan;

c. Non-Disclosure yaitu seandainyacalon tertanggung tidak menyampaikan suatu fakta karena ia mengira fakta tersebut tidak materiil (penting);

d. Concealment yaitu seandainya fakta-fakta materiil yang seharusnya diberitahukan kepada penanggung

\footnotetext{
${ }_{17}$ Bimbingan skripsi, tanggal 27 Desember 2007
} 
disembunyikan oleh calon tertanggung dengan sengaja.

Sehingga prinsip-prinsip yang dapat diterapkan dalam perjanjian asuransi jiwa adalah prinsip kepentingan atau insurable interest dan prinsip itikad baik atau utmost good faith principles. Prinsip-prinsip perjanjian asuransi jiwa ini kemudian dituangkan atau diimplementasikan dalam polis asuransi jiwa. Pada polis asuransi jiwa harus memuat antara lain yang disebutkan dalamPasal 304KUHD, yaitu hari ditutupnya pertanggungan, nama si tertanggung, nama orang yang jiwanya dipertanggungkan, saat mulai berlaku dan berakhirnya bahaya bagi si penanggung, jumlah uang untuk mana diadakan pertanggungan dan yang terakhir premi pertanggungan tersebut. Polis ini nantinya memiliki fungsi yang sangat penting antara lain sebagai dasar pelaksanaan hak dan kewajiban bagi penanggung dan tertanggung, merupakan alat bukti tertulis serta sebagai dasar penyelesaian sengketa.

\section{Pembatasan TanggungjawabPenanggung Dalam Asuransi Jiwa}

Perjanjian asuransi mempunyai sifat konsensuil, artinya bahwa secara hukum perjanjian asuransi sudah terbentuk sejak adanya kata sepakat. ${ }^{18}$ Sifat konsensuil ini diatur dalam Pasal 257 (1) KUHD yang menyebutkan bahwa "perjanjian pertanggungan diterbitkan seketika setelah ia ditutup, hak-hak dan kewajiban-kewajiban bertimbal-balik dari si penanggung dan si tertanggung mulai berlaku semenjak saat itu, bahkan sebelum polisnya ditanda tangani."

18 Catatan Kuliah "Hukum Asuransi" Semester 5 (tahun ajaran 2006).
Dalam pasal ini dijelaskan bahwa perjanjian asuransi dimulai pada saat kesepakatan antar pihak itu diucapkan, baik dengan cara tertulis maupun lisan.

Sejak adanya kata sepakat dari penanggung dan tertanggung untuk mengadakan perjanjian asuransi jiwa maka akan timbul kewajiban dari masing-masing pihak. Kewajiban utama dari penanggung dan tertanggung tersirat dalam Pasal 246 KUHD yaitu :

Asuransi atau pertanggungan adalah suatu perjanjian, dengan mana seorang penaggung mengikatkan diri kepada tertanggung, dengan menerima suatu premi, untuk memberikan penggantian kepadanya karena suatu kerugian, kerusakan atau kehilangan keuntungan yang diharapkan, yang mungkin akan dideritanya karena suatu peristiwa yang tak tertentu.

Ketentuan dalam Pasal 246 KUHD tersebut merupakan batasan atau definisi asuransi yang mencakup seluruh macam atau golongan asuransi, termasuk di dalamnya asuransi jiwa. Ketentuan dalam pasal ini mengandung unsur-unsur pokok dari perjanjian asuransi, unsur-unsur tersebut adalah :

a. Adanya pihak penanggung dan pihak tertanggung;

b. Adanya pembayaran premi oleh tertanggung;

c. Adanya jaminan oleh penanggung untuk membayar ganti rugi kepada tertanggung; 
d. Adanya peristiwa tidak pasti.

Maka jika ditelaah lebih lanjut kewajiban utama dari penanggung menurut Pasal 246 KUHD yaitu memberikan jaminan kepada tertanggung untuk mengganti kerugian, jika nantinya terjadi peristiwa tidak pasti dan kewajiban tersebut merupakan hak bagi tertanggung untuk menerima sejumlah uang sebagai bentuk pengalihan resiko.

Sedangkan kewajiban utama dari tertanggung adalah membayar uang premi secara berkala dan pembayaran premi inipun merupakan hak dari penanggung untuk menerimanya. Untuk tata cara pembayaran premi tidak diatur dalam KUHD, namun Pasal 256 (7) KUHD hanya menyebutkan bahwa jumlah premi harus dicantumkan didalam polis. Sehingga mengenai tata cara pembayaran, KUHD memberi kebebasan kepada para pihak yang berkepentingan untuk mengadakan perjanjian, asalkan perjanjian itu wajar dan dicantumkan secara tegas dalam akta perjanjian. ${ }^{19}$

Dalam asuransi jiwa, premi merupakan imbalan jasa atau jaminan perlindungan yang diberikan oleh penanggung kepada tertanggung dengan menyediakan sejumlah uang (benefit) terhadap resiko hari tua maupun resiko kematian. Bagi penanggung premi sangat penting karena dengan premi yang dikumpulkan dari tertanggung dalam waktu yang relatif lama diharapkan nantinya akan terkumpul dana yang besar, sehingga penanggung akan mampu untuk mengembalikan tertanggung pada keadaan semula (dalam segi ekonomi) seperti

\footnotetext{
19 Radiks Purba, op.cit, h. 116.
}

halnya sebelum peristiwa tidak pasti menimpanya. ${ }^{20}$

Pada perjanjian asuransi jiwa, premi tersebut digunakan oleh penanggung untuk membayar uang pertanggungan kepada penerima manfaat jika tertanggung pada masa pertanggungan meninggal dunia. Akan tetapi bila pada akhir masa pertanggungan, tertanggung masih hidup maka penanggung mempunyai kewajiban untuk membayar uang pertanggungan kepada tertanggung. Pembayaran uang pertanggungan ini bukanlah sebagai bentuk pembayaran ganti kerugian, melainkan sebagai suatu bentuk pemenuhan kewajiban yang telah disepakati oleh para pihak pada awal pembentukan perjanjian asuransi jiwa.

Akan tetapi tidak selalu pihak penanggung mempunyai kewajiban untuk membayar uang pertanggungan kepada tertanggung atau kepada penerima manfaat, karena KUHD mengatur mengenai pembatasan tanggungjawab penanggung dalam hal pembayaran uang pertanggungan. Sebab pertama penaggung tidak berkewajiban untuk membayar uang pertanggungan adalah apabila tertanggung pada masa pertanggungan tidak menjalankan kewajibannya dengan membayar premi secara berkala kepada penanggung. ${ }^{21}$

Pembayaran premi ini merupakan salah satu unsur pokok dalam perjanjian asuransi jiwa, sebagaimana yang diatur dalam Pasal 246 KUHD. Premi adalah suatu prestasi dari pihak tertanggung kepada penanggung. Sehingga jika tertanggung tidak membayar

\footnotetext{
${ }^{20}$ Radiks Purba, ibid, h. 105.

${ }^{21}$ Bimbingan Skripsi, tanggal 7 Desember 2007.
} 
uang premi maka dalam hal ini tertanggung dapat dikatakan wanprestasi atau lalai. Dengan demikian tertanggung telah melanggar perjanjian dengan melakukan atau berbuat sesuatu yang tidak boleh dilakukannya yaitu tidak membayar uang premi kepada penanggung. Maka ketika tertanggung wanprestasi, pihak penanggung dapat menolak klaim yang diajukan oleh tertanggung atau penerima manfaat.

Selain kewajiban untuk membayar premi kepada penanggung, dalam perjanjian asuransi jiwa tertanggung juga diwajibkan untukmemberikan keterangan atau informasi secara benar dan jujur tentang keadaan diri tertanggung, misalnya : kesehatannya, usianya dan tentang penyakit yang pernah diderita. Keterangan tersebut diberikan pada awal perjanjian asuransi jiwa diadakan dan ditulis dalam proposal form yang telah disediakan oleh perusahaan asuransi jiwa (penanggung).

Jika kewajiban tertanggung dengan memberi keterangan atau informasi adalah tidak sesuai dengan kenyataannya maka hal ini yang menjadi sebab kedua bagi penanggung untuk tidak berkewajiban membayar uang pertanggungan. Hal ini berkaitan dengan itikad baik dari tertanggung. Ketentuan ini diatur dalam Pasal 251 KUHD yang menyatakan bahwa :

Setiap keterangan yang keliru dan tidak benar, ataupun setiap tidak memberitahukan hal-hal yang diketahui oleh si tertanggung, betapapun itikad baik ada padanya, yang demikian sifatnya sehingga, seandainya si penanggung telah mengetahui keadaan yang sebenarnya, perjanjian itu tidak akan ditutup atau tidak akan ditutup dengan syarat-syarat yang sama, mengakibatkan batalnya pertanggungan.

Ada 2 (dua) kemungkinan tertanggung tidak memberikan keterangan atau informasi yang sebenarnya kepada penanggung, yaitu karena sengaja dan karena tidak disengaja. Jika tertanggung sengaja tidak memberikan keterangan atau informasi yang sebenarnya, penanggung tidak diwajibkan untuk membayar uang pertanggungan, karena dalam hal ini tertanggung dianggap tidak memiliki itikad baik sejak awal perjanjian asuransi jiwa diadakan. Tertanggung berusaha untuk menyembunyikan atau tidak menyampaikan keterangan atau informasi yang penting berkaitan dengan diri tertanggung kepada penanggung. Sehingga menyebabkan penanggung dapat menolak klaim yang diajukan kepadanya.

Lain halnya dengan tertanggung yang tidak disengaja lalai dalam memberikan keterangan atau informasi yang sebenarnya, hal ini dapat disebabkan karena kurang telitinya tertanggung dalam menyampaikan keterangan yang penting atau kurangnya pengetahuan tertanggung terhadap keadaan diritertangung sendiri.Sehinggatertanggung dengan demikian dianggap masih memiliki itikad baik. Namun menurut Pasal 251 KUHD, kesalahan tertanggung dalam memberikan keterangan atau informasi kepada penanggung meskipun tertanggung mempunyai itikad baik ataupun tidak, tetap mengakibatkan pertanggungan batal apabila 
penanggung dikemudian hari mengetahui keadaan yang sebenarnya.

Sebab ketiga penanggung tidak diwajibkan membayar uang pertanggungan yakni terkait dengan kepentingan tertanggung dalam perjanjian asuransi jiwa. Hal ini dapat dilihat dalam pasal 250 KUHD yaitu :

Apabila seseorang yang telah mengadakan suatu pertanggunganuntuk diri sendiri, atau apabila seseorang, yang untuknya telah diadakan suatu pertanggungan, pada saat diadakannya pertanggungan itu tidak mempunyai suatu kepentingan terhadap barang yang dipertanggungkan itu, maka si penanggung tidaklah diwajibkan memberikan ganti rugi.

Penjelasan pasal ini pada intinya yaitu harus adanya unsur kepentingan pada objek yang diasuransikan pada saat diadakannya pertanggungan. Jika tidak ada unsur kepentingan maka penanggung mempunyai hak untuk menolak klaim yang dimohonkan kepadanya. Ketentuan pasal ini tidak berarti kepentingan tertanggung harus ada pada saat mengadakan perjanjian asuransi atau pada saat pembentukan perjanjian asuransi, karena kepentingan tertanggung bukan merupakan syarat dalam pembentukan perjanjian asuransi tetapi kepentingan tertanggung hanya berkaitan dengan pelaksanaan tanggungjawab penanggung untuk membayar uang pertanggungan akibat terjadinya peristiwa tidak pasti untuk mana asuransi digantungkan. ${ }^{22}$

${ }^{22}$ Catatan Kuliah " Hukum Asuransi" Semester 5 (tahun ajaran 2006).
Hal ini diperkuat dengan adanya pendapat para sarjana hukum, antara lain Dorhout Mess dan Vollmar yang berpandangan bahwa kepentingan itu harus sudah ada pada saat terjadinya peristiwa sehingga tertanggung berhak menuntut ganti kerugian Dengan demikian menurut para sarjana hukum, kepentingan tidak perlu harus ada pada saat pertanggungan dibuat, melainkan pada saat terjadinya peristiwa yang menimbulkan kerugian itu. Hal ini karena pada saat itulah baru muncul kepentingan guna menentukan ada atau tidaknya ganti kerugian karena pada hakekatnya pertanggungan itu baru mempunyai arti bagi tertanggung justru pada saat terjadinya peristiwa tidak pasti. ${ }^{23}$

Asuransi jiwa merupakan pertanggungan dengan mana manusia (tertanggung) sebagai kepentingan yang diasuransikan. Dalam hal ini objek bahaya dari perjanjian asuransi jiwa adalah jiwa tertanggung. Perjanjian asuransi jiwa hanya boleh berlaku bila pemegang polis mempunyai kepentingan atas hidup orang yang jiwanya diasuransikan dan tidak boleh mencari keuntungan dengan mempertanggungkan jiwa tertanggung. Jika hal tersebut terjadi maka perjanjian asuransi jiwa akan batal demi hukum.

Untuk perjanjian asuransi jiwa, adanya unsur kepentingan tidak hanya terbatas pada kepentingan tertanggung tetapi dapat pula ditujukan untuk kepentingan pihak ketiga (penerima manfaat). Ketika tertanggung meninggal dunia maka pihak penerima manfaat dapat mengajukan klaim

${ }^{23}$ Abdulkadir Muhammad, op.cit, h. 42. 
asuransi jiwa kepada penanggung. Dari sinilah harus ada unsur kepentingan, pihak penanggung harus melihat apakah benar penerima manfaat mempunyai kepentingan atas meninggalnya tertanggung. Untuk itu penanggung dalam memberikan uang pertanggungan akan mengacu pada polis, dimana dalam polis telah dimuat nama dari penerima manfaat yang ditunjuk serta status atau hubungannya dengan tertanggung ketika nantinya tertanggung meninggal dunia.

Saat ini prinsip yang umum diakui adalah pertalian darah yang dekat atau pertalian hukum sudah cukup membuktikan adanya kepentingan yang dapat diasuransikan tanpa harus membuktikan adanya pertalian keuangan. Ini artinya hubungan suami istri, orang tua dan anak, kakek dengan cucu dan saudara sekandung sudah cukup untuk memenuhi persyaratan kepentingan yang dapat diasuransikan. Prinsip ini biasanya tidak berlaku untuk hubungan keluarga yang lebih jauh, seperti paman, tante dan keponakan.. Selain itu dalam hubungan bisnis, sejumlah keadaan dapat menimbulkan suatu kepentingan yang dapat diasuransikan. Sebagai contoh adalah majikan mempunyai kepentingan yang dapat diasuransikan dalam hidup pegawainya. Tetapi tetap saja, penerima manfaat mempunyai kewajiban untuk membuktikan bahwa dia adalah penerima manfaat yang ditunjuk oleh tertanggung. Hal ini dapat dibuktikan dengan menunjukkan polis asli dan identitas diri penerima manfaat kepada penanggung.

Sebab yang keempat penanggung tidak diwajibkan untuk membayar uang pertanggungan dalam perjanjian asuransi jiwa adalah terkait dengan kesalahan yang dilakukan tertanggung dalam masa pertanggungan. Kesalahan dari tertanggung memiliki pengertian yang luas yaitu segala macam kesalahan dalam bentuk kurang berhati-hati, tidak berhati-hati serta sembrono sedikit sampai sangat sembrono, dan sampai pula pada kesengajaan yang dilakukan oleh tertanggung. ${ }^{24}$

Kesalahan dari tertanggung ini, dalam asuransi jiwa diatur dalam Pasal 307 KUHD, yaitu mengenai tertanggung yang meninggal dunia karena bunuh diri atau dihukum mati pada masa pertanggungan. Artinya penanggung tidak bertanggungjawab atas kerugian yang terjadi karena kesalahan tertanggung (tidak terdapat ukuran disengaja maupun tidak disengaja) namun dalam hal ini harus diartikan bahwa kesalahan tersebut haruslah yang disengaja. ${ }^{25}$ Pasal ini juga memberi pengertian bahwa tertanggung sendirilah yang mempertanggungkan jiwanya, jadi bukan jiwa orang lain, dan dia sendirilah yang bunuh diri atau di hukum mati. $^{26}$

Konsep bunuh diri dalam asuransi jiwa ini tidak diatur dalam hukum pidana. Dalam hukum pidana hanya mengatur mengenai "bunuh diri" yang dilakukan dengan bantuan pihak ketiga dan/atau dilakukan dengan paksaan pihak ketiga.

${ }^{24}$ Wirjono Projodikoro, Hukum Asuransi di Indonesia, Djaya Pirusa, cetakan keenam, Jakarta, 1981, h.61.

${ }^{25}$ Catatan kuliah "Hukum Asuransi" semester 5 (tahun ajaran 2006).

${ }^{26}$ Catatan kuliah "Hukum Asuransi” semester 5 (tahun ajaran 2006) 
Maka jika dikaitkan dengan Pasal 307 KUHD, meninggalnya tertanggung dengan cara bunuh diri atau karena dihukum mati menurut pasal ini adalah perbuatan yang dilakukan dengan sengaja oleh tertanggung, tanpa bantuan maupun paksaan dari pihak lain. Sehingga penanggung tidak diwajibkan untuk membayar uang pertanggungan apabila nantinya penerima manfaat yang ditunjuk meminta pembayaran atas uang pertanggungan dari penanggung.

Dengan demikian terdapat beberapa pasal dalam KUHD yang mengatur tentang pembatasantanggungjawabolehpenanggung dalam melaksanakan kewajibannya terkait dengan perjanjian asuransi jiwa. Tujuan dari pembatasan tanggung jawab dari pihak penanggung adalah melindungi kepentingan penanggung dari itikad tidak baik yang dilakukan oleh tertanggung atau pemegang polis. Sehingga penanggung diberi hak untuk dapat menolak klaim yang dimohokan kepadanya.

\section{Klaim Atas Tertanggung Yang Meninggal Karena Bunuh Diri}

Salah satu tujuan dari diadakannya perjanjian asuransi jiwa adalah peralihan resiko dari tertanggung kepada penanggung. Menurutteoripengalihan resiko(risktransfer theory), tertanggung menyadari bahwa ada ancaman bahaya terhadap jiwanya. Jika bahaya tersebut menimpa jiwanya, dia akan menderita kerugian atau korban jiwa atau cacat raganya. Secara ekonomi, kerugian atas korban jiwa atau cacat raga akan mempengaruhi perjalanan hidup penerima manfaat atau ahli warisnya. ${ }^{27}$

Untuk mengurangi atau menghilangkan beban resiko tersebut, pihak tertanggung berupaya mencari jalan agar ada pihak lain (penanggung) yang bersedia mengambil alih beban resiko dan sebagai imbalannya dia sanggup membayar kontra prestasi yang disebut premi. Tertanggung mengadakan perjanjian asuransi jiwa dengan tujuan mengalihkan resiko yang mengancam jiwanya. Dengan harapan nantinya penanggung akan memberikan uang pertanggungan apabila terjadi kematian atas diri tertanggung. Akan tetapi untuk mendapatkan pembayaran uang pertanggungan, penerima manfaat yang ditunjuk harus mengajukan klaim kepada penanggung terlebih dahulu dengan memenuhi syarat-syarat yang telah diatur di dalam polis.

Pada dasarnya tidak semua permohonan klaim yang diajukan oleh penerima manfaat secara otomatis akan dibayar oleh penanggung (perusahaan asuransi jiwa), tetapi dari permohonan klaim tersebut harus dilakukan penelitian sebelumnya. Sehingga dari hasil penelitian tersebut dapat diketahui apakah meninggalnya tertanggung benarbenar diakibatkan oleh peristiwa tidak pasti yang telah disepakati dalam perjanjian asuransi jiwa yang dimuat dalam polis, atau bahkan meninggalnya tertanggung timbul karena kesalahan dari tertanggung sendiri. Ketentuan mengenai batasanbatasan tanggungjawab penanggung dalam melaksanakan kewajibannya kepada tertanggung telah diatur dalam

\footnotetext{
27 Abulkadir Muhammad , op.cit, h.12.
} 
polis asuransi jiwa, dimana pada masingmasing perusahaan asuransi jiwa memiliki kebijakan yang berbeda dalam menentukan batasan-batasan tersebut.

Setiap perusahaan asuransi jiwa, dalam hal ini bertindak sebagai penanggung, mempunyai kebijakan yang berlainan dalam menentukan apakah permohonan klaim dari tertanggung atau penerima manfaat dapat diterima atau tidak oleh penanggung. Hal ini bertujuan agar perjanjian asuransi jiwa tersebut tidak disalah gunakan oleh pihak-pihak yang terikat dalam perjanjian tersebut.

Mengenai tertanggung yang meninggal karena bunuh diri pada dasarnya di dalam Pasal 307 KUHD, hal tersebut termasuk pada klaim yang dapat ditolak oleh penanggung. Akan tetapi pada prakteknya PT Asuransi Jiwa Manulife Indonesia (selanjutnya disebut penanggung) memiliki kebijakan yang berbeda terhadap pembayaran klaim akibat tertanggung bunuh diri.

Dalam Pasal 15 huruf a Ketentuan Umum Polis PT Asuransi Jiwa Manulife Indonesia (selanjutnya ditulis dengan Ketentuan Umum Polis) terdapat ketentuan mengenai tertanggung yang meninggal karena bunuh diri yakni sebagai berikut :

Pertanggungan tidak berlaku apabila tertanggung meninggal dunia dalam keadaan sebagai berikut :

a. Terjadi dalam waktu 2 (dua) tahun terhitung sejak tanggal penerbitan Polis atau perubahannya (Addendum) yang terkini atau tanggal penerbitan pemulihan yang terkini (mana saja yang terjadii kemudian):

(1) Diakibatkan karena bunuh diri ; atau

(2) Menjalani eksekusi hukuman mati oleh Pengadilan.

Dalam pasal tersebut, pihak penanggung akan tetap membayar uang pertanggungan kepada penerima manfaat apabila meninggalnya tertanggung karena bunuh diri terjadi terhitung setelah 2 (dua) tahun sejak polis diterbitkan. Dalam penjelasan ini tertanggung sekaligus merupakan pemegang polis.

Hal ini dilakukan oleh penanggung karena tertanggung dianggap beritikad baik pada saat mengadakan perjanjian asuransi jiwa. Kebijakan penanggung tersebut cukup beralasan karena penanggung beranggapan bahwa dalam jangka waktu 2 (dua) tahun setelah polis diterbitkan, tindakan bunuh diri yang dilakukan oleh tertanggung dianggap bukanlah merupakan suatu tindakan yang semata-mata hanya untuk mendapatkan uang pertanggungan dari penanggung tetapi kemungkinan tindakan bunuh diri tersebut dilakukan oleh tertanggung karena adanya masalah pribadi, tekanan mental dan sebagainya. Jadi bukan suatu tindakan yang ada kaitannya dengan adanya perjanjian asuransi jiwa antara penanggung dan tertanggung.

Sedangkan bila tertanggung meninggal karena bunuh diri terjadi terhitung kurang dari 2 (dua) tahun sejak polis diterbitkan 
maka pihak penanggung akan menolak klaim yang diajukan kepadanya. Tetapi penanggung akan mengembalikan seluruh uang premi yang telah dibayarkan kepada penerima manfaat, dikurangi dengan seluruh manfaat pertanggungan yang telah diterima oleh pemegang polis dan seluruh biaya yang telah dikeluarkan oleh penanggung.

Hal ini dilakukan oleh penanggung karena jangka waktu kurang dari 2 (dua) tahun sejak polis diterbitkan, merupakan waktu yang relatif cepat. Sehingga wajar kiranya penanggung beranggapan bahwa tertanggung mengadakan perjanjian asuransi jiwa tersebut tidak dengan itikad baik dan ada kemungkinan semata-mata hanya untuk mendapatkan uang pertanggungan dalam waktu yang cepat. Maka dalam keadaan ini penanggung hanya akan mengembalikan uang premi yang telah dibayarkan oleh tertanggung dikurangi dengan seluruh manfaat pertanggungan yang telah diterima dan seluruh biaya yang telah dikeluarkan oleh penanggung. Pengembalian uang premi tersebut dibayarkan kepada penerima manfaat sebagai sebuah goodwill dari penanggung.

Dengan demikian ketentuan mengenai tertanggung yang meninggal karena bunuh diri menurut Pasal 307 KUHD berbeda dengan Ketentuan Umum Polis. Pada Pasal 307 KUHD mengatur bahwa penanggung dapat menolak klaim dari penerima manfaat jika tertangung meninggal karena bunuh diri. Pasal ini disimpangi dengan adanya Ketentuan Umum Polis yang mengatur bahwa pihak penanggung akan tetap membayar uang pertanggungan kepada penerima manfaat apabila meninggalnya tertanggung karena bunuh diri terjadi terhitung setelah 2 (dua) tahun sejak polis diterbitkan. Dalam PT Asuransi Jiwa Manulife Indonesia ketentuan ini diatur hanya untuk klaim individu.

Hal tersebut dimungkinkan terjadi karena penanggung, dalam halini perusahaan asuransi jiwa berbeda-beda sehingga setiap penanggung memiliki standart polis yang berbeda pula. Standar polis ini dibentuk atas dasar asas kebebasan berkontrak. Pengertian asas kebebasan berkontrak ini diatur di dalam Pasal 1338 (1) BW yakni "semua perjanjian yang dibuat secara sah berlaku sabagai undang-undang bagi mereka yang membuatnya." Sehingga pengertian dari asas kebebasan berkontrak adalah para pihak dalam membuat suatu perjanjian, termasuk perjanjian asuransi jiwa, berhak untuk menentukan isi atau klausula dari perjanjian itu sendiri. Tetapi dalam pembuatannya harus tetap memperhatikan syarat sahnya suatu perjanjian, adanya itikad baik dari para pihak dalam membuat suatu perjanjian dan perjanjian tersebut dibuat dengan tidak melanggar ketertiban umum, kesusilaan, dan undang-undang.

\section{Pengajuan dan Pembayaran Klaim Akibat Tertanggung Meninggal Karena Bunuh Diri}

Hal yang paling penting dalam asuransi jiwa adalah klaim dari tertanggung atau pemerima manfaat. Dalam melaksanakan kewajibannya terkait dengan pembayaran uang pertanggungan, pihak penanggung harus memperhatikan syarat-syarat khusus 
yang telah menjadi standar masing-masing perusahaanasuransi.Penentuansyarat-syarat khusus tersebut juga harus memperhatikan peraturan perundang-undangan, dengan kata lain tidak boleh menyimpang dari peraturan perundang-undangan yang berlaku di Indonesia. Untuk praktek bisnis asuransi di Indonesia, pihak penanggung menerapkan beberapa prosedural klaim yang berbeda, namun secara substansial pada dasarnya mempunyai kesamaan antara satu perusahaan asuransi dengan perusahaan asuransi yang lain. ${ }^{28}$

Sebenarnya untuk saat ini, seluruh perusahaan asuransi wajib untuk melakukan penyeragaman prosedural klaim yang menjadi guidelines bagi tertanggung atau penerima manfaat untuk melakukan klaim. Hal ini telah diatur dalam UU Usaha Perasuransian, dalam Pasal 11 (1) huruf b :

Pembinaan dan pengawasan terhadap usaha asuransi meliputi, penyelenggaraan usaha yang meliputi : syarat-syarat polis asuransi, tingkat premi, penyelesaian klaim, persyaratan keahlian di bidang perasuransian, dan ketentuan- ketentuan lain yang berhubungan dengan penyelenggaraan usaha.

Penjelasan Pasal 11 (1) huruf b, terkait dengan penyelesaian klaim adalah :

... Dalam rangka pembinaan dan pengawasan, peraturan pelaksanaan yang mencakup masalah penyelesaian klaim akan menetapkan batas waktu maksimum antara saat adanya kepastian

\footnotetext{
28 Chairul Huda dan Lukman Hakim,op.cit , h.20.
}

mengenai jumlah klaim yang harus di bayar dengan saat pembayaran klaim tersebut oleh Penanggung.

Selain diatur dalam Undang-Undang, Peraturan Pemerintah (PP) Nomor 73 tahun 1992 tentang Penyelenggaraan Usaha Perasuransian, dalam Pasal 23 (1) juga telah mengatur sebagai berikut: "Perusahaan asuransi atau perusahaan reasuransi dilarang melakukan tindakan yang dapat memperlambat penyelesaian atau pembayaran klaim, atau tidak melakukan tindakan yang seharusnya dilakukan yang dapat mengakibatkan kelambatan penyelesaian atau pembayaran klaim.“

Ketentuan peraturan perundangundangan diatas menjelaskan secara umum bahwa penanggung dilarang mempersulit atau menghambat pembayaran klaim asuransi yang diajukan oleh tertanggung atau penerima manfaat. Tetapi dalam peraturan perundang-undangan tersebut tidak diatur lebih rinci mengenai prosedur pengajuan dan pembayaran klaim asuransi. Dalam prakteknya, mengenai prosedur pengajuan klaim dan pembayarannya biasanya telah ditetapkan sendiri oleh penanggung. Pada saat menetapkan prosedur pengajuan dan pembayaran klaim inilah, pihak penanggung dilarang untuk membuat prosedur atau syarat-syarat yang dapat mempersulit tertanggung atau penerima manfaat untuk menerima uang pertanggungan. Sehingga untuk melindungi kepentingan pihak tertanggung dan penerima manfaat dibuatlah peraturan perundang-undangan tersebut.

Pada asuransi jiwa, pengajuan klaim 
atas tertanggung yang meninggal dunia karena bunuh diri dilakukan oleh penerima manfaat yang telah ditunjuk sebelumnya. Prosedur pengajuan klaim atas tertangung yang meninggal dunia karena bunuh diri pada dasarnya sama dengan prosedur pengajuan klaim atas tertanggung yang meninggal dunia karena sakit, kecelakaan atau sebabsebab lainnya. Perbedaannya hanya terletak pada berkas-berkas yang harus dilengkapi oleh penerima manfaat.

Pada prakteknya pengajuan klaim asuransi jiwa harus sesuai dengan ketentuan yang ada di dalam polis asuransi jiwa. Untuk PT Asuransi Jiwa Manulife Indonesia (selanjutnya disebut penanggung), ketentuan mengenai prosedur dan syaratsyarat pengajuan klaim diatur dalam Pasal 16.1 Ketentuan Umum Polis PT Asuransi Jiwa manulife Indonesia (selanjutnya ditulis Ketentuan Umum Polis) yaitu sebagai berikut :

\section{Pasal 16.1 Pemberitahuan}

a) Klaim wajib diajukan secara tertulis kepada penanggung;

b) Pengajuan klaim harus disertai berkasberkas asli sebagaimana dimaksaud dalam Pasal 16.2;

c) Berkas-berkas tersebut harus disampaikan dalam waktu 90 (sembilan puluh) hari terhitung sejak tertanggung meninggal atau akhir masa pertanggungan;

d) Apabila berkas-berkas tersebut tidak disampaikan dalam waktu yang ditentukan,maka penanggung mempunyai hak untuk menolak klaim yang bersangkutan;

e) Apabila berkas-berkas klaim sebagaimana dimaksud dalam pasal 16.2 tidak jelas, bertentangan atau tidak bersesuaian maka penanggung mempunyai hak untuk mendapat berkas lain atau penjelasan lebih lanjut.

Pada ketentuan diatas dapat dijelaskan bahwa pengajuan klaim harus disampaikan paling lambat 90 (sembilan puluh) hari terhitung sejak tertanggung meninggal dunia. Menurut ketentuan Pasal 16.1 huruf d, jika berkas-berkas tidak disampaikan pada waktu yang telah ditentukan (paling lambat 90 hari) maka penanggung mempunyai hak untuk menolak klaim tersebut. Tetapi apabila dalam waktu lebih dari 90 (sembilan puluh) hari penerima manfaat baru mengajukan klaim kepada penanggung karena alasanalasan tertentu maka penanggung biasanya tetap bersedia untuk menerima klaim tersebut. Pengajuan klaim oleh penerima manfaat dilakukan secara tertulis dengan menyertakan berkas-berkas yang diperlukan. Selanjutnya apabila berkas-berkas tersebut tidak jelas, tidak lengkap atau bahkan tidak sesuai dengan kenyataannya (fakta materiil) maka penanggung mempunyai hak untuk mendapatkan berkas lain atau menerima penjelasan lebih lanjut dari penerima manfaat.

Pada saat pengajuan klaim atas tertanggung yang meninggal dunia karena bunuh diri, berkas-berkas yang harus dilengkapi oleh pihak penerima manfaat 
$\operatorname{adalah}^{29}$ :

a) Polis;

b) Formulir klaim meninggal dunia asuransi individu yang disediakan oleh penanggung;

c) Surat keterangan dokter pemeriksa jenazah tertanggung, dengan menjelaskan sebab-sebab meninggalnya tertanggung;

d) Surat keterangan meninggal dari yang berwajib;

e) Kliping koran (jika ada).Surat keterangan mengenai bukti diri yang berkepentingan dalam polis (identitas penerima manfaat).

Apabila penerima manfaat telah melengkapi semua berkas yang disyaratkan di dalam polis, selanjutnya penanggung melakukan screaning terlebih dahulu guna meneliti atau menyelidiki kebenaran (fakta materiil) atas berkas-berkas tersebut. Apabila penanggung telah menerima serta menyetujui berkas-berkas tersebut maka untuk selanjutnya penanggung akan melakukan pembayaran uang pertanggungan melalui rekening milik penerima manfaat atau dengan cara transfer antar bank. Pembayaran uang pertanggungan tersebut menurut Pasal 16.3 huruf b Ketentuan Umum Polis, diperhitungkan dengan semua premi yang tertunggak dan kewajiban lainnya (bila ada). Jangka waktu pengajuan klaim sampai dengan pembayaran uang pertanggungan oleh penanggung kepada penerima manfaat kurang lebih membutuhkan waktu 20 (dua

29 Pasal 16.2 huruf a Ketentuan Umum Polis PT Asuransi Jiwa Manulife Indonesia. puluh) hari.

Tetapi apabila berkas tersebut tidak lengkap maka penanggung akan mengembalikannya kepada penerima manfaat untuk diberi waktu melengkapi berkas yang diperlukan tersebut. Dengan demikian penanggung belum dapat melakukan pembayaran uang pertanggungan sampai penerima manfaat melengkapi berkas tersebut. Tetapi bila ternyata terdapat unsur penipuan dan/atau pemalsuan pada berkas-berkas klaim yang diserahkan kepada penanggung, maka menurut Pasal 16.4 Ketentuan Umum Polis, penanggung mempunyai hak untuk menolak klaim dan/ atau membatalkan pertanggungan dasar dan/ atau pertanggungan tambahan (bila ada). Maka sangat diperlukan suatu itikad baik dari para pihak dalam melaksanakan pengajuan dan pembayaran uang pertanggungan dari penanggung kepada penerima manfaat.

Dengan demikian pengajuan klaim dari penerima manfaat kepada penanggung pada kenyataannya membutuhkan waktu yang relatif lama sedangkan dalam peraturan perundang-undangan di Indonesia yang mengatur mengenai asuransi mengharuskan agar klaim tersebut secepatnya dapat dibayarkan kepada penerima manfaat. Proses yang relatif lama tersebut pada dasarnya bertujuan untuk mengetahui secara pasti bahwa penerima manfaat adalah orang yang berkepentingan atas uang pertanggungan tersebut. Selain itu, proses tersebut juga sebagai bentuk tindakan antisipatif dari penanggung terhadap kemungkinan timbulnya masalah dikemudian hari. 


\section{KESIMPULAN}

1. Dalam KUHD diatur mengenai pembatasan tanggungjawab penanggung, dimana penanggung berhak menolak klaim yang diajukan oleh tertanggung atau penerima manfaat. Pembatasan tanggungjawab Tersebut jika dikaitkan dengan tertanggung yang meninggal karena bunuh diri adalah Pasal 307 KUHD memberi hak kepada penanggung untuk menolak klaim dari penerima manfaat karena pertanggungannya dianggap gugur. Hal ini karena dengan meninggalnya tertanggung akibat bunuh diri maka tertanggung dianggap tidak memiliki itikad baik dalam menjalankan pertanggungannya.

2. Ketentuan dalam Pasal 307 KUHD, berbeda dengan Pasal 15 huruf a Ketentuan Umum Polis Asuransi Jiwa PT Manulife Indonesia. Pada Ketentuan ini, penanggung (PT Manulife Indonesia) akan tetap membayar uang pertanggungan kepada penerima manfaat apabila meninggalnya tertanggung karena bunuh diri terjadi terhitung setelah 2 (dua) tahun sejak polis diterbitkan. Hal ini dilakukan sebagai bentuk nyata itikad baik dari penanggung. Sehingga dalam prakteknya, pembayaran klaim akibat tertanggung meninggal karena bunuh diri yang diterapkan oleh PT Asuransi Jiwa Manulife Indonesia tidak sesuai dengan Pasal 307 KUHD. Prosedur pengajuan dan pembayaran klaim sepenuhnya diserahkan kepada para pihak. Untuk prosedur pembayaran uang pertanggungan dimana tertanggung meninggal akibat bunuh diri, sama dengan prosedur pembayaran uang pertanggungan pada umumnya.

Sehingga dari kesimpulan tersebut dapat diberikan saran sebagai berikut:

1. Perjanjian asuransi jiwa harus dilaksanakan dengan prinsip itikad baik dari para pihak. Selain itu sebelum mengadakan perjanjian asuransi jiwa, setiap penanggung sebaiknya dalam melakukan proses penjualan produk asuransi jiwa selalu menggunakan pendekatan untuk mengetahui kebutuhan calon tertanggung atau pemegang polis. Seperti yang telah dilakukan PT Asuransi Jiwa Manulife Indonesia, dengan menggunakan sistem Priority Choice, yang memberikan kesempatan bagi pemegang polis atau tertanggung untuk mendiskusikan berbagai macam kebutuhan yang dimilikinya kemudian menetapkan prioritas kebutuhan mana yang lebih dulu harus dipenuhi. Setelah prioritas kebutuhan ditetapkan, calon tertanggung atau pemegang polis akan diberikan solusi bagaimana kebutuhan itu bisa dipenuhi sesuai dengan kemampuan membayar premi. Sehingga nantinya pemegang polis atau tertanggung dalam melaksanakan perjanjian asuransi jiwa dapat merasakan manfaat dari polis yang dimilikinya karena produk asuransi yang diikuti 
merupakan keinginan dan kebutuhan dari pemegang polis atau tertanggung sendiri.

2. Adanyaanggapansebagianmasyarakat yang menyatakan pembayaran sebuah klaim asuransi jiwa selalu dipersulit harus dicarikan solusinya. Dalam hal inilah pemerintah melalui Departemen Keuangan/ Bapepam-LK diharapkan mampu mengeluarkan pedoman atau ketentuan mengenai prosedur pembayaran klaim asuransi jiwa, khususnya terkait dengan tertanggung yang meninggal karena bunuh diri. Hal ini penting agar perkembangan industri asuransi jiwa di Indonesia dapat ditingkatkan seperti di negaranegara maju dimana industri asuransi jiwa memegang peranan penting di dalam perkembangan ekonomi suatu negara.

\section{DAFTAR BACAAN}

\section{BUKU :}

Campbel,Henry, Black's Law Dictionary, ST Paul, MINN, West Publishing Co, 1990

Huda,Chairul dan Lukman Hakim, Tindak Pidana Dalam Bisnis Asuransi, Lembaga Pemberdayaan Hukum Indonesia (LPHI), cetakan pertama, Jakarta, 2006, h.4. dikutip dari M.Suparman dan Endang, Hukum Asuransi (Perlindungan Tertanggung, Asuransi Deposito, Usaha Perasuransian), Alumni, Bandung, 2003

Muhammad,Abdulkadir, Pokok-Pokok Hukum Pertanggungan, Citra
Aditya Bakti, cetakan ketiga, Jakarta, 1977

Prakoso,Djoko, Hukum Asuransi Indonesia, Rineka Cipta, Jakarta, 2004, h. 281 dikutip dari Ny Dani Pangaribuan Simanjuntak, Hukum Pertanggungan (Pertanggungan kerugian pada umumnya, keakaran dan jiwa),Seksi Hukum Dagang Fakultas Universitas Gajah Mada, Yogyakarta, 1975

Projodikoro,Wirjono, Hukum Asuransi di Indonesia, Djaya Pirusa,cetakan keenam, Jakarta, 1981

Radiks Purba, Memahami Asuransi di Indonesia, Pustaka Binaman Pressindo, seri umum ke 10, Jakarta, 1992

Subekti, Hukum Perjanjian, Intermasa, cetakan keduapuluhsatu, Jakarta, 2005

Suparman Sastrawidjaja,M, AspekAspek Hukum Asuransi dan Surat Berharga,Alumni, Bandung, 1997

Ketentuan Umum Polis PT Asuransi Jiwa Manulife Indonesia

\section{WEBSITE :}

$\underline{\text { www.wikipedia.com }}$

www.pesankonsumen.com

$\underline{\text { www.republika..com }}$ 